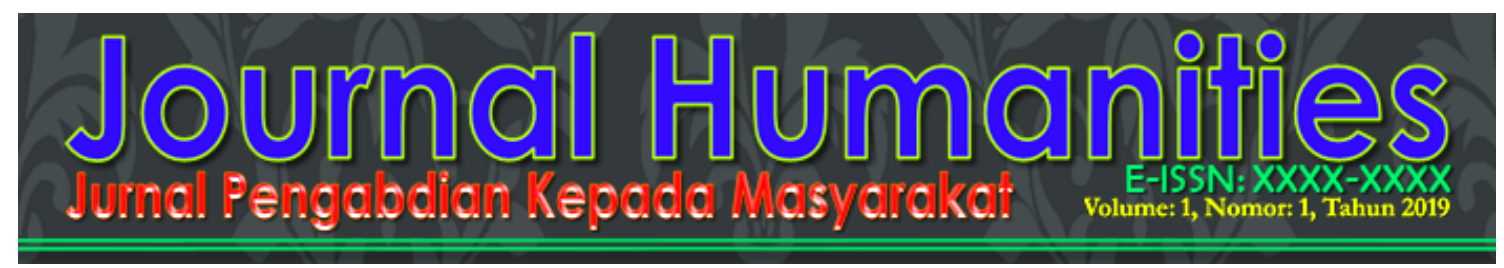

\title{
EFFORTS TO INCREASE PROFESSIONALITY OF TEACHER OF BEGINNING OF ELEMENTARY SCHOOL TEACHERS THROUGH TRAINING OF FRIRAGE MASSAGE THERAPY
}

\author{
Rosmaneli $^{1}$, Ali Umar ${ }^{2}$ Darni $^{3}$, Eldawaty ${ }^{4}$ \\ ${ }^{1234}$ Jurusan Pendidikan Olahraga, Fakultas Ilmu Keolahragaan \\ Universitas Negeri Padang \\ Email: rosmaneli@fik.unp.ac.id ${ }^{1}, \underline{\text { aliumar@ fik.unp.ac.id }}{ }^{2}, \underline{\text { darni@ fik.unp.ac.id }}{ }^{3}$, \\ eldawaty@fik.unp.ac.id ${ }^{4}$
}

\begin{abstract}
The problem underlying this training is that the Physical Education teacher's knowledge and skills are not yet optimal in providing treatment / prevention in schools, either because of practical or sport learning activities, or in the service of UKS activities. The methods used in this training are lectures, discussions, questions and answers, demonstrations or demonstrations, methods of practice and practice. The results of the evaluation of 30 trainees were: (a) 13 people $(\mathbf{4 3 . 3 3 \%})$ received an A or Excellent score, (b) 16 people $(53.33 \%$ ) received a B or Good rating, (c) 1 person (3.33\%) get a $\mathrm{C}$ or sufficient value; and (d) the average value of achievement of training competency is $\mathbf{7 6 . 5 2}(\mathbf{7 7 . 6 4 \%})$ with a grade of $B$ or Good.

Keywords: Frirage Massage Therapy Training

\section{UPAYA PENINGKATAN PROFESIONALITAS GURU PENJASORKES SEKOLAH DASAR NEGERI MELALUI PELATIHAN TERAPI PEMIJATAN FRIRAGE}

\begin{abstract}
Abstrak
Masalah yang melatarbelakangi pelatihan ini adalah belum optimalnya pengetahuan dan keterampilan guru Penjasorkes dalam memberikan pengobatan/ pencegahan di sekolah, baik karena kegiatan pembelajar praktek atau olahraga, maupun dalam pelayanan kegiatan UKS. Metode yang digunakan dalam pelatihan ini adalah ceramah, diskusi, tanya jawab, demonstrasi atau peragaan, metode latihan dan praktek. Hasil evaluasi terhadap 30 orang peserta pelatihan adalah: (a) 13 orang $(43,33 \%)$ memperoleh nilai A atau Baik Sekali, (b) 16 orang $(53,33 \%)$ memperoleh nilai B atau Baik, (c) 1 orang (3,33\%) memperoleh nilai C atau cukup; dan (d) nilai rata-rata pencapaian kompetensi pelatihan adalah 76,52 (77,64\%) dengan nilai B atau Baik.

Kata Kunci: Pelatihan Terapi Pemijatan Frirage.
\end{abstract}

10 | Efforts To Increase Professionality Of Teacher Rosmaneli ${ }^{1}$, Zainul Johon ${ }^{2}$ Darni $^{3}$, Nirwandi ${ }^{4}$ http://jha.ppj.unp.ac.id 


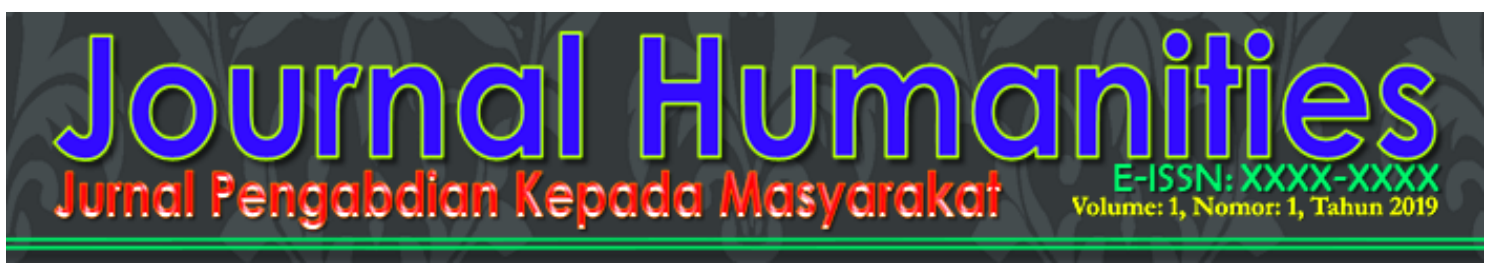

ANALISIS SITUASI

Satu-satunya mata pelajaran yang difokuskan pada aktivitas fisik atau jasmani di tingkat Sekolah Dasar (SD) adalah mata pelajaran Pendidikan Jasmani Olahraga dan Kesehatan (Penjasorkes). Oleh karena itu, pembelajaran penjasorkes lebih banyak dalam bentuk praktek olahraga di luar kelas atau di lapangan. Ketika pembelajaran di luar kelas atau lapangan tersebut melaksanakan pembelajaran praktek atletik, senam, olahraga permainan, penjelajahan lingkungan, berkemah, renang, dan sebagainya.

Aktivitas fisik yang dilakukan siswa dalam pembelajaran praktek Penjasorkes tersebut, berpotensi merugikan kesehatan siswa. Beberapa contoh akibat melakukan olahraga yang merugikan kesehatan tersebut seperti: nyeri otot, pegal-pegal, kelelahan, masuk angin, pusing muntah-muntah, pingsan dan sebagainya.

Untuk mengantisipasi berbagai akibat melakukan olahraga yang merugikan maka guru Penjasorkes bukan hanya dituntut untuk memiliki profesionalitas yang tinggi dalam pengelolaan materi, metode dan media pembelajaran, tetapi juga harus dibekali dengan kemampuan praktek untuk melakukan pencegahan dan pengobatan.

Pentingnya profesionalitas guru Penjasorkes dalam hal pengobatan atau pencegahan penyakit secara praktis tersebut, akan semakin nyata jika dikaitkan dengan peran mereka sebagai Guru Pembina Usaha Kesehatan Sekolah (UKS). Sebagai Guru Pembina UKS, mereka bukan hanya dituntut memberikan pendidikan kesehatan, dan pembinaan lingkungan sekolah sehat, tetapi juga harus mampu memberikan pelayanan kesehatan sebagaimana diharapkan dalam Trias UKS. Dalam upaya peningkatan profesionalitas guru Penjasorkes tersebut, maka kepada mereka penting dibekali dengan 


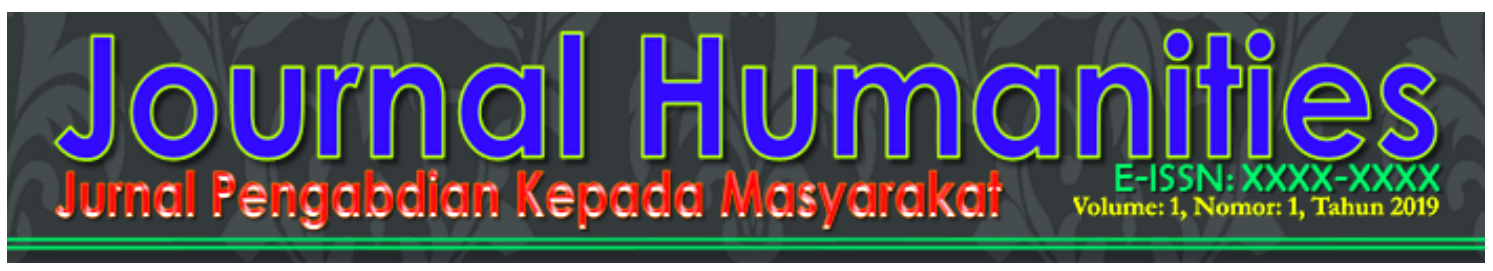

kemampuan pemijatan frirage. Dikatakan demikian, karena kemampuan memberikan

pemijatan merupakan salah satu aspek dari profesionalitas seorang guru Penjasorkes.

Depdiknas (2005:702) menjelaskan bahwa, "profesionalitas adalah kepandaian khusus untuk melaksanakan profesi”. Pemijatan frirage dapat diartikan sebagai kepandaian khusus (profesionalitas) yang harus dimiliki guru Penjasorkes, terutama sekali di SD.

Hal ini dimungkinkan oleh lebih rentannya siswa SD mendapatkan berbagai gangguan kesehatan di sekolah, dibandingkan dengan jenjang sekolah yang lebih tinggi. Dengan demikian, pengetahuan dan keterampilan melakukan pemijatan frirage, bukan saja dibutuhkan dalam pengelolaan pembelajaran praktek/ olahraga guna mengantisipasi gangguan kesehatan, tetapi juga, untuk memberikan layanan pengobatan sebagai bagian dari kegiatan UKS.

Kondisi ideal yang digambarkan di atas, berbeda dengan realitas yang ada. Artinya, guru Penjasorkes SD pada umumnya belum memiliki pengetahuan/ keterampilan yang optimal dalam. memberikan pengobatan di sekolah. Permasalahan kurang optimalnya profesionalitas guru dalam memberikan layanan, pengobatan tersebut dapat diidentifikasi, karena: (1) Minimnya obat-obatan yang disediakan di sekolah; (2) Kurang optimalnya pengelolaan kegiatan UKS; (3) Terbatasnya sarana/ prasarana UKS yang ada di Sekolah; dan (4) Terbatasnya pengetahuan dan keterampilan guru Penjasorkes tentang pengobatan alternatif melalui terapi pemijatan.

Terapi pemijatan Frirage merupakan gabungan dari terapi pemijatan China dengan terapi pemijatan tradisional Jawa yang bertujuan untuk mencegah atau 


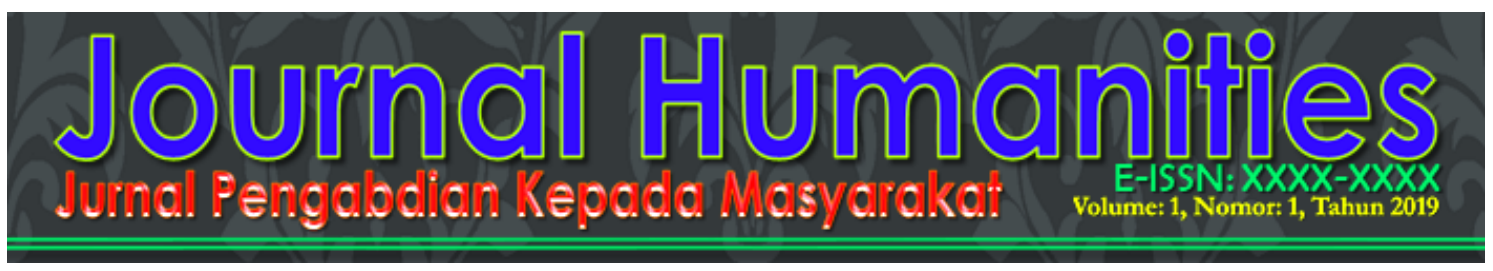

mengobati bermacam penyakit. Dengan demikian, pengetahuan/ keterampilan pemijatan

frirage akan sangat diperlukan guru sebagai pengobatan alternatif terhadap siswa yang mengalami gangguan kesehatan di sekolah.

Berdasarkan penjajakan awal yang kami lakukan, diperoleh masukan bahwa sebanyak 30 orang guru Penjasorkes SD Negeri di Kecamatan Bungus Teluk Kabung Kota Padang, berminat untuk mendapatkan pengetahuan dan keterampilan pemijatan frirage.

\section{SOLUSI DAN TARGET}

Solusi untuk mengatasi permasalahan minimnya profesionalisme guru Penjasorkes dalam aspek pengobatan dan pencegahan penyakit secara praktis, baik untuk kepentingan pembelajaran praktik olahraga, maupun kegiatan UKS, perlu diadakan pelatihan terapi pemijatan frirage bagi guru Penjasorkes SD Negeri di Kecamatan Bungus Teluk Kabung Kota Padang.

Kegiatan pengabdian kepada masyarakat dalam bentuk terapi pemijatan frirage ini ditampilkan dengan dua kelompok materi pelatihan, yaitu aspek pengetahuan (kognitif) dan keterampilan (psikomotor). Untuk aspek pengetahuan sebanyak $25 \%$ dan keterampilan $75 \%$. Ditargetkan, pelatihan ini selesai dalam waktu maksimal 6 (enam) bulan, dengan tingkat penguasaan minimal $75 \%$ dari keseluruhan materi pelatihan.

\section{METODE PELAKSANAAN}

\section{Tempat dan Waktu}

Tempat pelaksanaan pengabdian masyarakat dalam bentuk pelatihan terapi pemijatan frirage ini adalah di gedung SD Negeri 20 Lubuk Tarok Kecamatan Bungus 


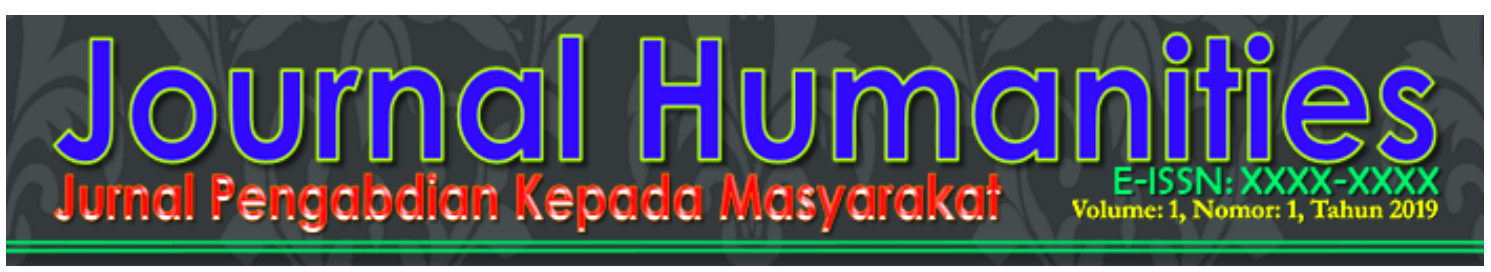

Teluk Kabung Kota Padang. Waktu pelaksanaan kegiatan adalah tanggal 27 - 28

September 2019.

\section{Khalayak Sasaran}

Khalayak sasaran pelatihan adalah guru mata pelajaran Penjasorkes pada SD Negeri di Kecamatan Bungus Teluk Kabung Kota Padang yang berjumlah 30 orang.

\section{Metode Pengabdian}

Menyesuaikan dengan bentuk materi pelatihan, materi yang berbentuk pengetahuan dilatihkan dengan metode ceramah, diskusi dan tanya jawab. Sementara itu, materi yang berbentuk keterampilan dilatihkan dengan metode demonstrasi (peragaan), latihan dan praktek.

\section{Indikator Keberhasilan}

Indikator keberhasilan pelatihan ini dilihat dari dua aspek, yaitu proses dan hasil. Dari aspek proses, pelatihan ini dikatakan berhasil dengan indikator: (1) Pelatihan terlaksana sesuai jadwal; (2) Tersedianya sarana dan prasarana pelatihan; (3) peserta pelatihan terlibat aktif dalam pembahasan materi pelatihan; dan (4) peserta pelatihan menunjukkan tingkat kehadiran/ absensi yang tinggi.

Dilihat dari aspek hasil, pelatihan ini dikatakan berhasil jika peserta dapat menguasai materi, baik aspek pengetahuan maupun keterampilan. Indikator keberhasilan untuk masing-masing aspek materi tersebut ditampilkan dalam Tabel 1 berikut: 


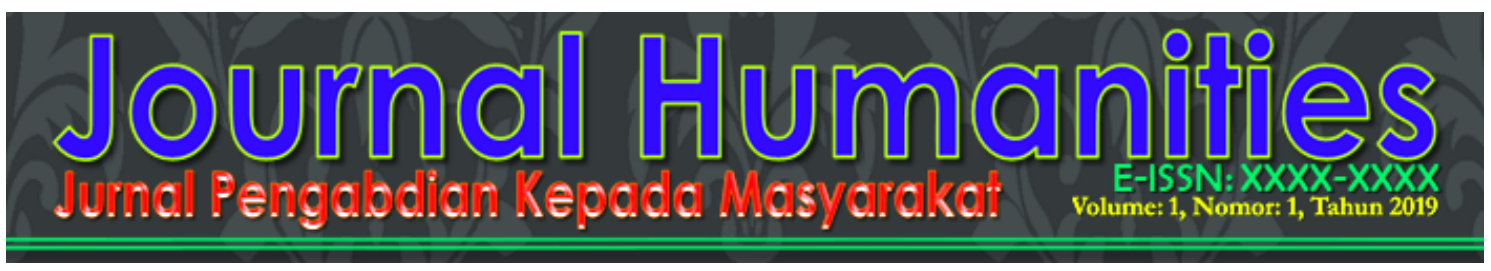

Tabel 1 Indikator Keberhasilan Pelatihan Dilihat dari Aspek Materi

\begin{tabular}{|c|c|c|}
\hline Materi & Indikator Keberhasilan & Aspek \\
\hline $\begin{array}{l}\text { 1. Pengetahuan dasar } \\
\text { terapi pemijatan } \\
\text { frirage }\end{array}$ & $\begin{array}{l}\text { 1.1. Mengenal sejarah ringkas masase } \\
\text { 1.2. Memahami pengertian frirage } \\
\text { 1.3. Memahami pengertian friction } \\
\text { 1.4. Memahami pengertian effleurage } \\
\text { 1.5. Menyebutkan alat/ bahan praktek } \\
\text { pemijatan frirage/ masase }\end{array}$ & $\begin{array}{l}P \\
P \\
P \\
P \\
P\end{array}$ \\
\hline $\begin{array}{l}\text { 2. Pengetahuan dasar } \\
\text { anatomi dan fisiologi } \\
\text { tubuh manusia }\end{array}$ & $\begin{array}{l}\text { 2.1. Menyebutkan hubungan dan letak bagian- } \\
\text { bagian tubuh manusia } \\
\text { 2.2. Mengetahui tujuan pemijatan frirage } \\
\text { terhadap perbaikan kebugaran fisiologis } \\
\text { 2.3. Mengetahui tujuan pemijat terhadap } \\
\text { perbaikan fungsi anatomi }\end{array}$ & $\begin{array}{l}\mathrm{P} \\
\mathrm{P} \\
\mathrm{P}\end{array}$ \\
\hline $\begin{array}{l}\text { 3. Keterampilan } \\
\text { dasar pemijatan } \\
\text { frirage }\end{array}$ & $\begin{array}{l}\text { 3.1. Dapat memperagakan manipulasi friction } \\
\text { dengan benar } \\
\text { 3.2. Dapat memperagakan manipulasi frirage } \\
\text { dengan benar } \\
\text { 3.3. Dapat menunjukkan titik tengah } \\
\text { 3.4. Dapat menunjukkan sisi samping } \\
\text { 3.5. Dapat menunjukkan titik pijat di telapak } \\
\text { tangan } \\
\text { 3.6. Dapat menunjukkan titik pijat di telapak } \\
\text { kaki }\end{array}$ & $\begin{array}{l}\mathrm{K} \\
\mathrm{K} \\
\mathrm{K} \\
\mathrm{K} \\
\mathrm{K} \\
\mathrm{K}\end{array}$ \\
\hline $\begin{array}{l}\text { 4. Praktek pemijatan } \\
\text { frirage pada, titik } \\
\text { pijat (accupoint) }\end{array}$ & $\begin{array}{l}\text { 4.1. Dapat memperagakan pemijatan untuk } \\
\text { perbaikan fungsi organ kepala } \\
\text { 4.2. Dapat memperagakan pemijatan untuk } \\
\text { perbaikan fungsi organ mata } \\
\text { 4.3. Dapat memperagakan pemijatan untuk } \\
\text { perbaikan fungsi organ } \\
\text { 4.4. Dapat memperagakan pemijatan untuk } \\
\text { perbaikan fungsi telinga } \\
\text { 4.5. Dapat memperagakan pemijatan untuk } \\
\text { perbaikan fungsi organ gigi } \\
\text { 4.6. Dapat memperagakan pemijatan untuk } \\
\text { perbaikan fungsi organ leher } \\
\text { 4.7. Dapat memperagakan pemijatan untuk } \\
\text { perbaikan fungsi organ paru-paru } \\
\text { 4.8. Dapat memperagakan pemijatan untuk } \\
\text { perbaikan fungsi organ paru-paru jantung } \\
\text { 4.9. Dapat memperagakan pemijatan untuk } \\
\text { perbaikan fungsi organ lambung } \\
\text { 4.10. Dapat memperagakan pemijatan untuk }\end{array}$ & $\begin{array}{l}\mathrm{K} \\
\mathrm{K} \\
\mathrm{K} \\
\mathrm{K} \\
\mathrm{K} \\
\mathrm{K} \\
\mathrm{K} \\
\mathrm{K} \\
\mathrm{K} \\
\mathrm{K}\end{array}$ \\
\hline
\end{tabular}

15 | Efforts To Increase Professionality Of Teacher

Rosmaneli ${ }^{1}$, Zainul Johon ${ }^{2}$ Darni $^{3}$, Nirwandi ${ }^{4}$

http://jha.ppj.unp.ac.id 


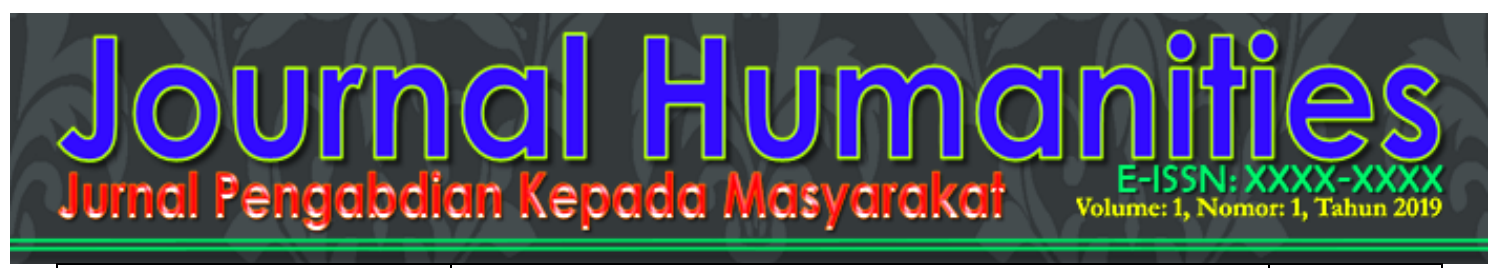

\begin{tabular}{|c|c|c|}
\hline Materi & Indikator Keberhasilan & Aspek \\
\hline & $\begin{array}{l}\text { perbaikan fungsi organ liver } \\
\text { 4.11. Dapat memperagakan pemijatan untuk } \\
\text { perbaikan fungsi organ empedu } \\
\text { 4.12. Dapat memperagakan pemijatan untuk } \\
\text { perbaikan fungsi organ pancreas } \\
\text { 4.13. Dapat memperagakan pemijatan untuk } \\
\text { perbaikan fungsi organ usus } \\
\text { 4.14. Dapat memperagakan pemijatan untuk } \\
\text { perbaikan fungsi organ ginjal } \\
\text { 4.15. Dapat memperagakan pemijatan untuk } \\
\text { perbaikan fungsi organ kelenjar adrenalin } \\
\text { 4.16. Dapat memperagakan pemijatan untuk } \\
\text { perbaikan fungsi organ saluran kantong kemih } \\
\text { 4.17. Dapat memperagakan pemijatan untuk } \\
\text { perbaikan fungsi organ dinding rahim } \\
\text { 4.18. Dapat memperagakan pemijatan untuk } \\
\text { perbaikan fungsi organ testis } \\
\text { 4.19. Dapat memperagakan pemijatan untuk } \\
\text { perbaikan fungsi organ ovari }\end{array}$ & $\begin{array}{l}\mathrm{K} \\
\mathrm{K} \\
\mathrm{K} \\
\mathrm{K} \\
\mathrm{K} \\
\mathrm{K} \\
\mathrm{K} \\
\mathrm{K} \\
\mathrm{K}\end{array}$ \\
\hline & Jumlah Kompetensi Minimal (33) & $\begin{aligned} \mathrm{P} & =8 \\
\mathrm{~K} & =25\end{aligned}$ \\
\hline
\end{tabular}

Keterangan:

$\mathrm{P}=$ Pengetahuan

$\mathrm{K}=$ Keterampilan

Indikator keberhasilan penggunaan materi pelatihan minimal dengan tingkat penguasaan $75 \%$ atau dengan kategori baik.

\section{Metode Evaluasi}

Metode evaluasi pelatihan ini menyesuaikan dengan bentuk materi yang dilatihkan. Untuk materi yang berbentuk pengetahuan, yaitu: (1) pengetahuan dasar terapi pemijatan frirage, dan (2) pengetahuan dasar anatomi dan fisiologi tubuh manusia, dievaluasi dengan metode tertulis. Untuk materi aspek keterampilan, yaitu: (1) keterampilan dasar pemijatan frirage, dan (2) praktek pemijatan pada titik pijat 


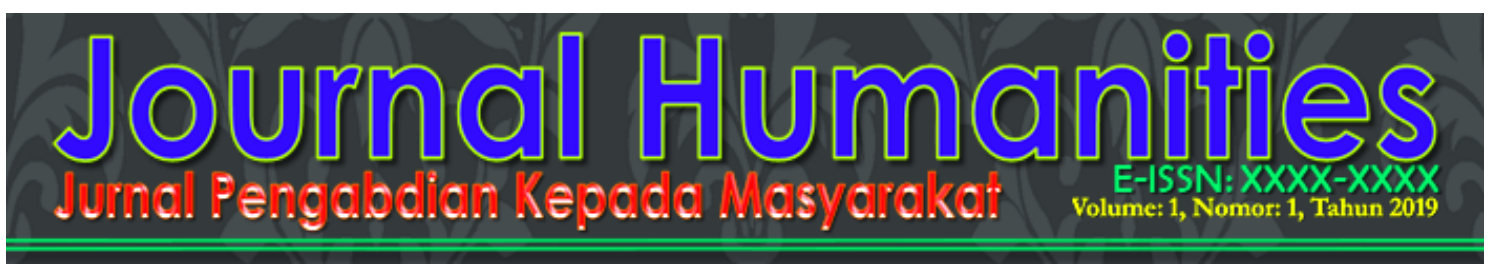

(accupoint), dievaluasi dengan tes perbuatan. Dalam hal ini peserta pelatihan diminta

berbuat (memeragakan/ mendemonstrasikan) materi keterampilan yang dieveluasikan tersebut.

Rata-rata persentase (\%) penguasaan materi pengetahuan dan keterampilan yang dicapai peserta selanjutnya dikonversikan dengan tabel 2 berikut sebagai kriteria pembanding. Dengan demikian diperoleh nilai huruf dan kategori hasil evaluasi pelatihan ini.

Tabel 2 Kriteria Pembanding Untuk Menyimpulkan Hasil Evaluasi Pelatihan

\begin{tabular}{|c|c|c|}
\hline $\begin{array}{c}\text { Persentase (\%) } \\
\text { Penguasaan Materi }\end{array}$ & Nilai Huruf & Kategori \\
\hline $80-100$ & A & Baik sekali \\
\hline $66-79$ & B & Baik \\
\hline $56-65$ & C & Cukup \\
\hline $40-55$ & D & Kurang \\
\hline $30-39$ & E & Gagal \\
\hline
\end{tabular}

Sumber: Daryanto (2005: 211)

\section{HASIL DAN PEMBAHASAN}

Hasil pelatihan ini adalah sebagai berikut: (1) dari 30 orang peserta latihan terdapat 13 orang $(43,33 \%)$ yang memperoleh nilai A atau dengan kategori Baik sekali, 16 orang $(53,33 \%)$ yang memperoleh nilai B atau dengan kategori Baik; 1 orang (3,33\%) memperoleh nilai $\mathrm{C}$ atau dengan kategori Cukup; dan (2) rata-rata capaian kompetensi peserta pelatihan adalah 76,52 (77,64\%) dengan nilai B atau kategori Baik.

Keberhasilan peserta pelatihan mencapai hasil yang cukup menggembirakan sebagaimana dikemukakan di atas, dapat dibahas dari beberapa aspek berikut: 


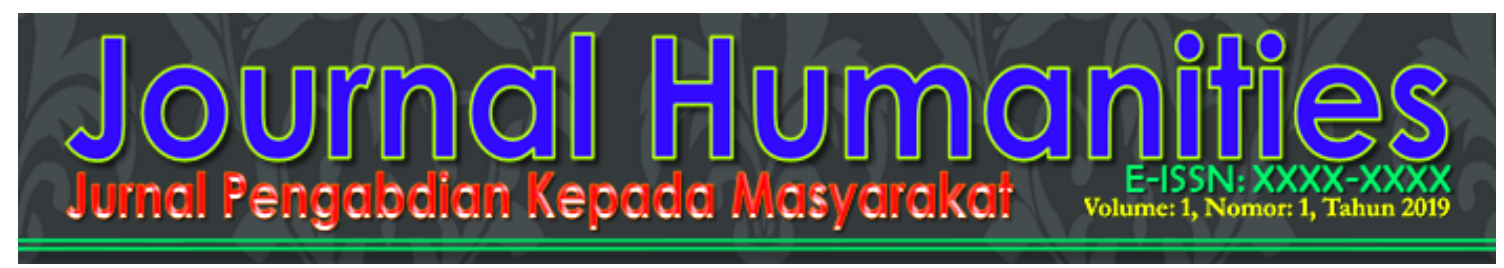

\section{Dari Aspek Materi}

Dari aspek materi, dalam pelatihan ini dikembangkan materi atau bahan hasil identifikasi kebutuhan. Rae (1990: 12) mengemukakan, "Identifikasi kebutuhan diperlukan karena adanya prestasi yang tidak mencapai tingkat yang diharapkan”. Dengan arti kata, materi pelatihan berupa pengetahuan dan keterampilan tercapai pemijatan frirage merupakan hasil identifikasi terhadap kebutuhan guru Penjasorkes. Artinya, guru Penjasorkes SD Negeri di Kecamatan Bungus Teluk Kabung Kota Padang belum pernah mendapatkan materi tentang pemijatan frirage yang seharusnya dimiliki oleh mereka. Materi pemijatan frirage akan sangat dibutuhkan oleh guru Penjasorkes dalam memberikan pengobatan di sekolah, baik dalam pengelolaan pembelajaran praktek maupun dalam pelaksanaan kegiatan UKS.

Oleh karena itu, para guru Penjasorkes peserta pelatihan ini dapat merasakan bahwa pengetahuan/ keterampilan tercapai pemijatan frirage merupakan suatu kebutuhan untuk peningkatan profesionalitas mereka. Hal ini akan tampak lebih jelas jika dikaitkan dengan pelaksanaan pembelajaran sebagaimana dikemukakan Lutan (2001:11) bahwa:

Pendidikan Jasmani yang berkualitas membutuhkan bimbingan secara langsung dan gunanya. Di samping dibutuhkan bimbingan untuk mencapai proses pertumbuhan. Pendidikan Jasmani berpotensi mengancam aspek keselamatan siswa.

Berdasarkan kutipan di atas, dapat dimengerti bahwa untuk melaksanakan pembelajaran Pendidikan Jasmani (Penjasorkes) yang bermutu, diperlukan bimbingan secara langsung dari gurunya, karena pembelajaran Penjasorkes tersebut berpotensi mengancam keselamatan siswa. Sebagai contoh: kegiatan praktek olahraga di bawah 


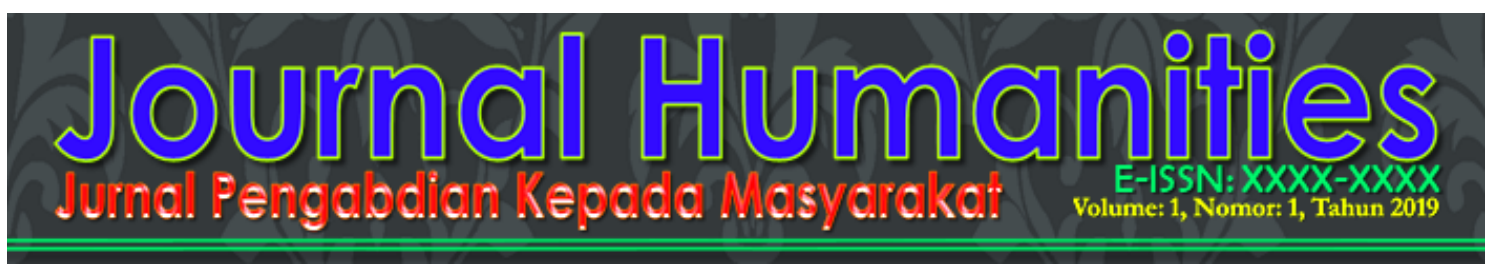

terik matahari dapat menimbulkan sakit kepala, pingsan, dan sebagainya. Kegiatan

praktek yang tidak sesuai dengan kemampuan fisik siswa, dapat menyebabkan terkilir (leseleo), kelalaian yang berlebihan dan sebagainya. Dengan demikian jelaslah bahwa pengetahuan dan keterampilan terapi pemijatan frirage merupakan suatu kebutuhan yang harus dilatihkan kepada guru Penjasorkes. Pengetahuan dan keterampilan pemijatan frirage akan dapat membekali guru Penjasorkes dengan kemampuan pengobatan alternatif

\section{Dari Aspek Metode}

Metode merupakan cara atau teknik yang digunakan oleh pelatih/ instruktur untuk menyajikan materi tertentu dalam suatu pelatihan. Rae (1990:3) menggambarkan orientasi metode beberapa tahun yang lalu.

Beberapa tahun yang lalu, pelatihan hampir seluruhnya terpusat pada penatar. Ia menentukan sasaran pelatihan, waktu, isi, dan bentuknya. Penatar sepenuhnya mengendalikan arah pelatihan. Pendapat para peserta pelatihan jarang diminta dan jika diminta dilakukan dengan sangat terbatas.

Kutipan di atas mendeskripsikan orientasi metode pelatihan yang berpusat pada penatar/ instruktur. Pendapat atau tanggapan peserta pelatihan jarang diminta jika diminta hanya dilakukan secara terbatas. Kenyataan di atas, berbeda dengan pendekatan metode dalam pelatihan ini. Metode pelatihan yang digunakan disesuaikan dengan bentuk materi yang akan dilatihkan. Untuk materi dengan aspek pengetahuan, digunakanmetode diskusi, ceramah, tanya jawab. Sementara itu, untuk materi dengan aspek keterampilan digunakan metode tugas, demontrasi dan penugasan. Dengan menggunakan multimetode (banyak metode) tersebut, maka proses penyajian materi 


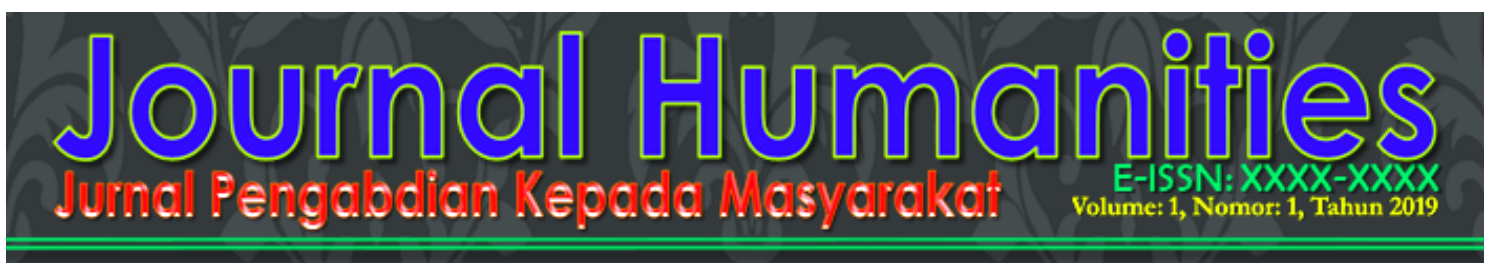

pelatihan berlangsung secara aktif Komunikasi antara penatar/ instruktur dengan peserta

pelatihan, berlangsung secara timbal balik atau multiarah. Oleh karena penyerapan materi pengetahuan dan keterampilan terapi pemijatan frirage dapat dikuasai dengan lebih baik.

\section{Dari Aspek Motivasi Mengikuti Pelatihan}

Secara sederhana, motivasi dapat diartikan sebagai pendorong atau penyebab seseorang untuk melakukan aktivitas tertentu. Begitu juga dengan peserta pelatihan, terapi pemijatan firage, juga punya motivasi tertentu. Pada umumnya, motivasi dibedakan atas dua macam, yakni motivasi instrinsik dan ekstrinsik. Imran (1996:88) menjelaskan sebagai berikut:

Secara garis besar, motivasi dapat dibedakan menjadi dua, yaitu motivasi instrinsik dan ekstrinsik. Motivasi instrinsik adalah motivasi yang berasal dari dalam tanpa ada rangsangan dari luar sedangkan motivasi ekstrinsik adalah motivasi yang berasal dari luar.

Sesuai kutipan di atas, motivasi dibedakan menjadi dua macam, yakni motivasi instrinsik atau yang berasal dari dalam diri, dan motivasi ekstrinsik atau yang berasal dari luar diri individu.

Jika dikaitkan dengan tingginya pencapaian rata-rata persentase penguasaan kompetensi minimal materi pelatihan, tampaknya peserta pelatihan pemijatan frirage memiliki kedua bentuk motivasi tersebut. Dengan kata lain, di samping didorong oleh motivasi instrintik, peserta pelatihan terapi pemijatan frirage, juga didorong oleh motivasi ekstrinsik. 


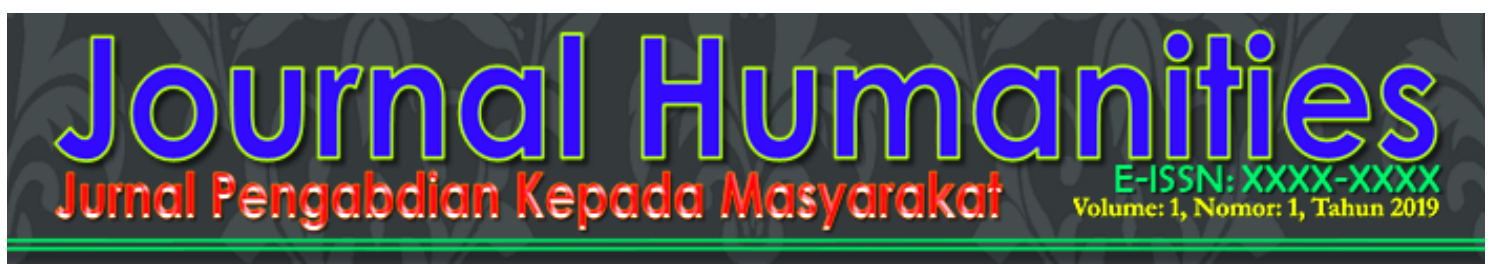

Dari hasil wawancara penuis dengan peserta pelatihan, didapatkan gambaran

bahwa mereka memiliki motivasi instrinsik yang cukup kuat, misalnya: dorongan atau harapan yang besar untuk menguasai pengetahuan/ keterampilan pemijatan ftirage agar memiliki keahlian untuk melakukan pengobatan dengan pemijatan. Di samping memiliki motivasi instrinsik, peserta pelatihan atau guru Penjasorkes di SD Negeri di Kecamatan Bungus Teluk Kabung Kota Padang, juga didorong oleh motivasi ekstrinsik (dari luar diri) misalnya: mengikuti pelatihan pemijatan frirage dikarenakan ingin mendapatkan sertifikat pelatihan. Bukti administratif berupa sertifikat pelatihan akan dijadikan oleh guru Penjasorkes tersebut untuk menambah persyaratan perhitungan angka kredit guna kenaikan pangkat/golongan.

\section{Dari Aspek Tempat Pelatihan}

Sebagaimana diketahui, pelatihan terapi pemijatan frirage ini dilaksanakan di ruang/ gedung SD Negeri 20 Lubuk Tarok Kecamatan Bungus Teluk Kabung Kota Padang. Situasi di tempat ini sangat sejuk dan terawat dengan baik, tumbuhan hijau dan hembusan angin laut di sekitarnya juga memberikan nuansa keindahan dan kesejukan.

Dengan kata lain, dari aspek tempat, pelaksanaan terapi pemijatan frirage telah didukung oleh tempat pelatihan yang relatif baik. Hal ini tentu akan memberikan pengaruh terhadap hasil belajar yang dapat dicapai.

Sebaliknya, jika suatu tempat pelatihan menyediakan tempat yang tidak memadai, misalnya: ruangan yang terlalu sempit dibandingkan jumlah peserta yang relatif banyak, udara yang panas atau tidak sejuk, dan keadaan sekitarnya yang tidak ditata secara rapi, tentu hasil belajar yang dicapai tidak sebagaimana mestinya.

\section{1 | Efforts To Increase Professionality Of Teacher}

Rosmaneli $^{1}$, Zainul Johon ${ }^{2}$ Darni $^{3}$, Nirwandi ${ }^{4}$

http://jha.ppj.unp.ac.id 


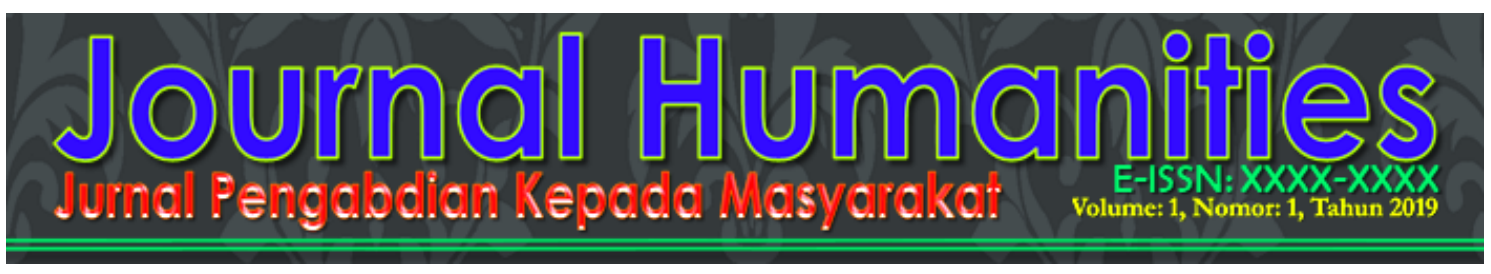

\section{KESIMPULAN}

Kesimpulan pelatihan ini adalah sebagai berikut:

1. Peserta pelatihan ini adalah guru Penjasorkes SD Negeri di Kecamatan Bungus Teluk Kabung Kota Padang yang berjumlah 30 orang.

2. Materi yang dikembangkan dalam pelatihan ini adalah: (a) pengetahuan dasar terapi pemijatan frirage; (b) Pengetahuan dasar anatomi; (c) keterampilan dasar pemijatan frirage; dan (d) praktek pemijatan frirage pada titik pijat (accupoint).

3. Hasil evaluasi dari 30 orang peserta pelatihan ini adalah: (a) 13 orang $(43,33 \%)$ memperoleh nilai A atau dengan kategori Baik sekali; (b) 16 orang $(53,33 \%)$ memperoleh nilai $\mathrm{B}$ atau dengan kategori Baik; (c) 1 orang $(3,33 \%)$ memperoleh nilai C atau dengan kategori cukup; dan (d) Nilai rata-rata capaian kompetensi peserta pelatihan adalah 76,52 (77,64\%) dengan nilai B atau kategori Baik.

\section{DAFTAR PUSTAKA}

Bambang, Ali Setia Graha. 2004. Terapi Pemijatan Frirage. Yogyakarta, FIK UNY

Basoeki, Sunarjo. 1973. Massage. Jakarta: Direktorat jenderal Olahraga dan Pemuda.

Darni, 2008. "Pemijatan Frirage Cara Sehat dan. Dua Jari”. Makalah Seminar Nasional Lokakarya Kurikulum Model Pembelajaran Kelas dan Pelatihan Massage, Padang 19-21 April.

Darni, 2009. Massage Olahraga Dasar Teori dan Manipulasi. Wineka Media, Malang.

Daryanto. 2005. Evaluasi Pendidikan. Jakarta: Rineka Cipta

Depdikbud, 1980/1981. Sport Massage. Jakarta, Direktorat Jenderal Olahraga dan Pemuda.

Imron, Ali. 1996. Belajar dan Pembelajaran. Jakarta: Pustaka Jaya

\section{2 | Efforts To Increase Professionality Of Teacher}

Rosmaneli ${ }^{1}$, Zainul Johon ${ }^{2}$ Darni $^{3}$, Nirwandi ${ }^{4}$

http://jha.ppj.unp.ac.id 


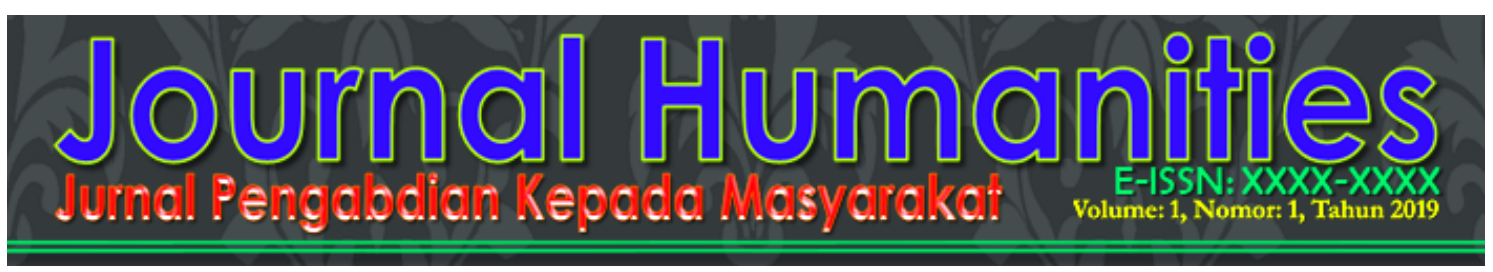

Lutan, Rusli. 2001. Mengajar Pendidikan Jasmani Pendekatan Pendidikan Gerak di Sekolah Dasar. Jakarta: Direktorat Jenderal Olahraga.

Mashoed. 1980/1981. Masase Olahraga Pertolongan Pertama pada Kecelakaan dan Pendidikan Keselamatan. Jakarta: PT. New Aqua.

Rae, Leslie, 1990, Mengukur Efektivitas Pelatihan. Jakarta: PT. Pustaka Binamas Pressindo. 